DOI: https://doi.org/10.33330/jurteksi.v6i3.623

Available online at http://jurnal.stmikroyal.ac.id/index.php/jurteksi

\title{
ANALISIS SISTEM INFORMASI KUALITAS PRODUKSI SULAMAN MAYANG DENGAN MENGGUNAKAN METODE MC CALL
}

\author{
Firna Yenila ${ }^{1^{*}}$, Eva Rianti $^{1}$ \\ ${ }^{1}$ Sistem Informasi, Fakultas Ilmu Komputer, Universitas Putra Indonesia YPTK Padang \\ email: *firnayenila@upiyptk.ac.id
}

\begin{abstract}
Sulaman Mayang's Industry has implemented a desktop-based system in data processing, a one-way system involving only one actor/user of the system. So that in use there are some new problems that have arisen that affect the performance of services to customers. This study aims to analyze and test the quality of the Mayan embroidery information system using the McCall method. Analysis is carried out on several aspects of the product operation including the quality factors of correctness (truth), reliability (reliability), efficiency (efficiency), integrity (integrity) and usability (usability). Data was collected through questionnaires from 38 respondents involving workers/employees and customers. The results showed that overall the quality of the Sulaman Mayang information system was at the level of $76 \%$ (the quality of the information system was good according to the scale interpretation of the percentage of quality factors). Thus the quality of Mayang embroidery information systems needs to be improved in accordance with recommendations which are improvements to the quality of Mayan embroidery information systems.
\end{abstract}

Keywords: McCall Method; Sulaman Mayang; the quality of information system.

\begin{abstract}
Abstrak: Industri Sulaman mayang sejauh ini menerapkan sistem berbasiskan dekstop dalam pengolahan data, sistem yang digunakan satu arah hanya melibatkan satu aktor/pengguna sistem saja. Sehingga dalam penggunaan ada beberapa persoalan baru yang bermunculan yang mempengaruhi kinerja layanan terhadap pelanggan. Penelitian ini bertujuan untuk menganalisa dan menguji kualitas sitem informasi sulaman mayang dengan meggunakan metode McCall. Analisa dilakukan terhadap beberapa aspek dalam product operation diantaranya faktor kualitas correctness (kebenaran), reliability (keandalan), effisiensy (efisien), integrity (integritas) dan usability (kegunaan). Data dikumpulkan melalui kuosioner dari 38 responden yang melibatkan pekerja/karyawan dan pelanggan. Hasil penelitian menunjukkan bahwa secara keseluruhan kualitas sistem informasi sulaman mayang berada pada level 76\% (kualitas sistem informasi tersebut baik menurut skala penafsiran persentase faktor kualitas). Dengan demikian kualitas sistem informasi sulaman mayang perlu ditingkatkan sesuai dengan rekomendasi yang merupakan perbaikan kualitas sistem informasi sulaman mayang.
\end{abstract}

Kata kunci: kualitas sistem informasi; metode McCall; Sulaman Mayang 
DOI: https://doi.org/10.33330/jurteksi.v6i3.623

Available online at http://jurnal.stmikroyal.ac.id/index.php/jurteksi

\section{PENDAHULUAN}

Industri-industri rumah tangga saat ini berlomba-lomba dalam menyajikan informasi yang efektif dan efisien kepada pelanggan dalam hal pendistribusian produk yang dibuat [1]. Salah satu industri rumah tangga yang menggunakan teknologi sistem informasi tersebut adalah Sulaman Mayang Pariaman, yang memberikan kemudahan dalam hal transaksi kepada pelanggan melalui aplikasi berbasiskan dekstop. Aplikasi tersebut memberikan kemudahan pada pihak pengelola untuk memberikan informasi mengenai data produk yang akan di distribusikan kepada pelanggan, jumlah produk yang tersisa dan jenis produk yang dihasilkan sehingga pelaporan data keuangan dalam aplikasi ini jelas dan mudah didapatkan oleh owner ketika dibutuhkan.

Kualitas sistem perangkat lunak disinyalir merupakan sebuah elemen kritis dari jaminan kualitas perangkat lunak dan merepresentasikan kajian pokok dari spesifikasi, disain dan pengkodean [2]. Kualitas perangkat lunak dilihat dari sudut pandang proses pengembangan perangkat lunak (process) dan hasil produk yang akan dihasilkan [3]. Hasil penelitian perangkat lunak dapat dikembangkan sesuai dengan yang diharapkan oleh pengguna [4].

Aplikasi pendistribusian sulaman di sulaman mayang baru digunakan pada tahun 2017 yang masih kurang komunikatif terhadap produk yang akan di distribusikan kepada pelanggan. Pelanggan memiliki kesulitan dalam melihat informasi mengenai sulaman yang diinginkan karena aplikasi pendistribusian sulaman ini dibuat dengan java netbeans dan database MySQL yang berbasiskan dekstop sehingga tertutup untuk pelanggan. Dari sistem yang sudah ada, pelanggan hanya mendapatkan informasi berupa penjelasan langsung dari pelanggan mengenai sulaman yang diinginkan. Untuk hal tersebut maka pengguna diharuskan datang langsung ke toko Sulaman Mayang, banyaknya pelanggan yang datang menyebabkan terlambatnya pelayanan yang didapatkan oleh pelanggan tersebut. Sehingga perlu dilakukan pengujian terhadap kualitas produk sulaman mayang tersebut.

Pengujian perangkat lunak terhadap pendistribusian sulaman mayang tersebut dilakukan dengan metode McCall. Metode McCall merupakan suatu kriteria yang mempengaruhi perangkat lunak [5]. Metode tersebut menitikberatkan pada tiga factor, yaitu: (1) Product revision, (2) Product Transaction, (3) Product Operation. Hal tersebut digambarkan dalam bentuk bagan sebagai berikut:

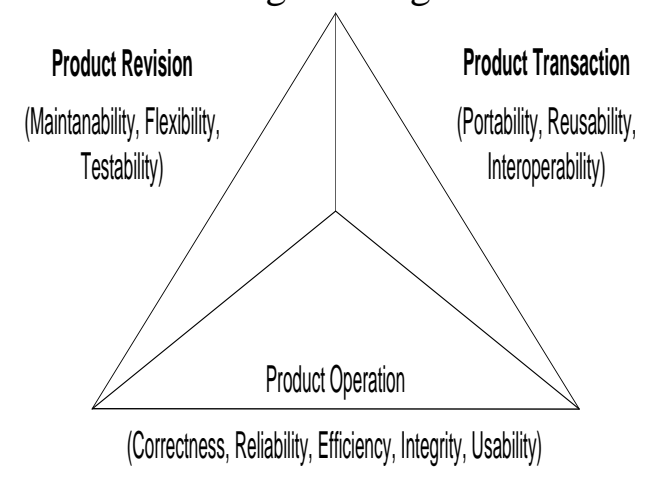

Gambar 1. Bagan Metode McCall

Berdasarkan gambar 1 diketahui bahwa kualitas yang berhubungan dengan product operation diantaranya faktor kualitas correctness (kebenaran) yang merupakan suatu software yang diharapkan mampu memenuhi kebutuhan fungsional yang telah ditetapkan dan kebutuhan fungsional yang tersirat[5]; reliability (keandalan) adalah salah satu perangkat lunak yang 
DOI: https://doi.org/10.33330/jurteksi.v6i3.623

Available online at http://jurnal.stmikroyal.ac.id/index.php/jurteksi

mampu melaksanakan fungsinya dengan ketelitian yang diperlukan untuk mengetahui seberapa besar sistem mengalami kegagalan [8]; efficiency (Efisiensi) dikaitkan dengan sumber daya sistem yang dibutuhkan [9]; Integrity dinyatakan sebagai sejauh mana jangkauan akses sebuah sistem sehingga terlindungi dari serangan yang merusak keamanan sistem tersebut [10]; usability berkaitan dengan cakupan sumber daya manusia yang dibutuhkan berupa pegawaai baru dan melatih pegawai baru yang akan menggunakan perangkat lunak[7]. Usability dikaitkan dengan kemudahan dalam menggunakan software atau perangkat lunak[5].

Tujuan penelitian ini adalah untuk mengetahui dan meningkatkan kualitas sistem informasi di Sulaman Mayang hingga mengetahuai sejauhmana kekurangan dan kelemahan sistem informasi Sulaman Mayang. Pengujian kualitas perangkat lunak merupakan suatu proses yang digunakan untuk mengidentifikasi ketepatan, kelengkapan dan mutu dari perangkat lunak. Hasil penelitian ini diharapkan dapat menjadi salah satu acuan untuk para pengelola dalam mengembangkan aplikasi di kemudian hari yang lebih efektif dan efisien.

\section{METODE}

Dalam penelitian ini, kerangka penelitian yang dilakukan dapat dilihat dari gambar 2.

Instrument penelitian yang digunakan berupa kuosioner yang diberikan kepada pihak karyawan selaku pengguna aplikasi sistem informasi sulaman mayang dan pelanggan yang akan memberikan opini terhadap hasil produksi sulaman dengan menggunakan skala likert (1-5) menurut Tarmudin [11] seperti pada tabel 1, sedangkan untuk mutu atau bobot penilaian yang digunakan dalam setiap faktor kualitas serta bobot dari setiap matrik terdapat pada tabel 2.

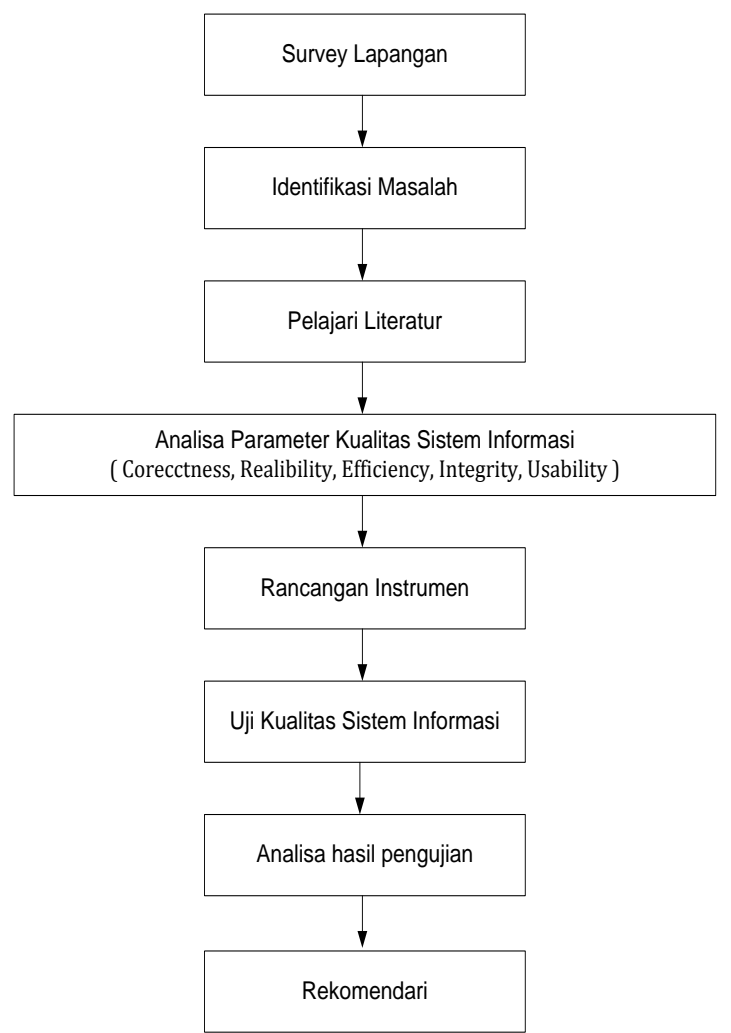

Gambar 2. Bagan Metode McCall

Tabel 1. Skala Likert

\begin{tabular}{cl}
\hline Skala Penilian & \multicolumn{1}{c}{ Keterangan } \\
\hline 1 & Sangat tidak setuju \\
\hline 2 & Tidak setuju \\
\hline 3 & Netral \\
\hline 4 & Setuju \\
\hline 5 & Sangat setuju \\
\hline
\end{tabular}

Tabel 2. Mutu faktor kualitas dan matrik

\begin{tabular}{cl}
\hline $\begin{array}{c}\text { Skala } \\
\text { Penilaian }\end{array}$ & \multicolumn{1}{c}{ Keterangan } \\
\hline 0.4 & Sangat penting \\
\hline 0.3 & Penting \\
\hline 0.2 & Cukup penting \\
\hline 0.1 & Tidak penting \\
\hline
\end{tabular}


DOI: https://doi.org/10.33330/jurteksi.v6i3.623

Available online at http://jurnal.stmikroyal.ac.id/index.php/jurteksi

Rancangan berikutnya adalah menciptakan instrumen pertanyaan yang mengacu kepada teori McCall. Analisis data kuotioner dilakukan dengan cara kuantitatif deskriptif yang merupakan penjelasan langsung dari hasil kalkulasi yang menggunakan rumus McCall [6]. Kemudian melakukan olah data persentase yang menggunakan persamaan. Nilai persentase merujuk pada kategori kualitas menurut Arikunto yang ditampilkan pada tabel 3 .

Tabel 3 Persentase faktor kualitas

\begin{tabular}{cc}
\hline Kategori & Persentase \\
\hline Sangat baik & $81 \%-100 \%$ \\
\hline Baik & $61 \%-80 \%$ \\
\hline Cukup & $41 \%-60 \%$ \\
\hline Tidak Baik & $21 \%-40 \%$ \\
\hline Sangat tidak baik & $<21 \%$ \\
\hline
\end{tabular}

Adapun tahapan dalam menghitung pengujian kualitas dengan menggunakan metode McCall adalah sebagai berikut [12]:

1. Menentukan

kriteria/matrik/parameter yang akan digunakan dalam mengukur faktor kualitas

2. Menentukan bobot (w) dari setiap kriteria faktor kualitas $(0 \leq w \leq 1)$

3. Menentukan skala nilai yang mengacu pada tabel 1 yaitu skala likert yang menyatakan bahwa nilai 1 adalah nilai minimum dan nilai 5 adalah batas maksimum.
4. Mamasukkan nilai pada tiap kriteria hasil dari penilian responden, lalu menghitung nilai rata-ratanya.

5. Menghitung nilai total dengan rumus persamaan:

$\mathrm{F} \alpha=\mathrm{w} 1 \mathrm{c} 1+\mathrm{w} 2 \mathrm{c} 2+\ldots+$ wncn............ (1)

$\mathrm{F} \alpha$ : Nilai total dari fator $\alpha$ wn : Bobot untuk kriteria $\mathrm{n}$ cn : nilai untuk kriteria $\mathrm{n}$

6. Menghitung persentase nilai faktor kualitas dengan menggunakan persamaan:

Persentase $=\frac{\text { Nilai yang didapat }}{\text { Nilai maksimum }} \times 100 \%$

\section{HASIL DAN PEMBAHASAN}

\section{Analisis Hasil Penelitian}

Aktifitas berikutnya adalah melakukan pengumpulan data melalui penyebaran kuesioner yang dilakukan secara online ataupun offline dengan melibatkan 38 responden. Data yang didapatkan dari pengisian kuesioner oleh 52 responden yang disebarkan oleh owner Sulaman Mayang terdapat pada tabel 4. Owner sulaman mayang mengisi data bobot untuk masing-masing faktor kualitas dan bobot untuk masing-masing parameter. Data kriteria akan dilihat berdasarkan skala likert yang berasal dari data kuesioner yang diisi oleh responden tersebut.

Penelitian akan dilanjutkan dengan menentukan total $\mathrm{Fa}$ yang didasari oleh faktor kualitas McCall, apabila nilai bobot dan rata kriteria didapatkan. 
DOI: https://doi.org/10.33330/jurteksi.v6i3.623

Available online at http://jurnal.stmikroyal.ac.id/index.php/jurteksi

Tabel 4. Hasil Penilaian Kualitas Sistem Informasi Sulaman Mayang

\begin{tabular}{|c|c|c|c|c|}
\hline No & $\begin{array}{l}\text { Faktor } \\
\text { Kualitas }\end{array}$ & Metrik Dan Parameter & $\frac{8}{0}$ & 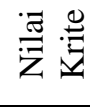 \\
\hline \multirow[t]{8}{*}{1} & \multirow{8}{*}{ 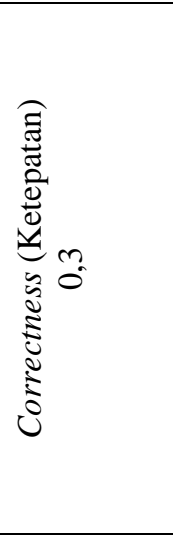 } & a. Completeness (Kelengkapan) & & \\
\hline & & $\begin{array}{l}\text { 1. Aplikasi ini mampu melakukan proses pengolahan data } \\
\text { (penampilan data) }\end{array}$ & 0,4 & 4,13 \\
\hline & & 2. Fitur -Fitur Yang terdapat pada sitem ini sudah berfungsi semua & 0,4 & 3,87 \\
\hline & & $\begin{array}{l}\text { b. Consistency (Konsistensi) } \\
\text { 3. Tampilan dan rancangan tabel memiliki kesamaan disetiap } \\
\text { halaman }\end{array}$ & 0,2 & 4,71 \\
\hline & & 4. Fitur dan desain form dan tombol di setiap halaman sama & 0,2 & 3,74 \\
\hline & & $\begin{array}{l}\text { 5. Bahasa yang ada dalam sistem tersebut konsisten di setiap } \\
\text { halaman }\end{array}$ & 0,3 & 4,68 \\
\hline & & 6. Bentuk dan struktur pelaporan pengolahan data sama & 0,2 & 4,00 \\
\hline & & $\begin{array}{l}\text { c. Treacebility (Pelacakan) } \\
\text { 7. Dapat melacak pendistribusian yang dilakukan }\end{array}$ & 0,4 & 4,00 \\
\hline \multirow[t]{9}{*}{2} & \multirow{9}{*}{ 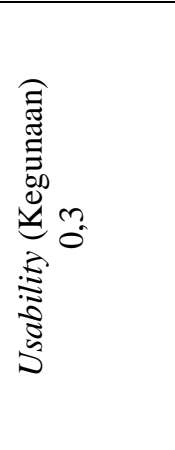 } & d. Communicativeness (Komunikatif) & & \\
\hline & & 8. Memudahkan pemahaman bahasa & 0,4 & 4,18 \\
\hline & & 9. Tulisan dari setiap halaman dapat terbaca dengan jelas & 0,4 & 4,08 \\
\hline & & 10. Fungsi dari setiap tombol jelas & 0,4 & 3,82 \\
\hline & & e. Operability (Operabilitas) & & \\
\hline & & 11. Pilihan alat bantu dari sistem yang ada memudahkan pengguna & 0,4 & 3,82 \\
\hline & & $\begin{array}{l}\text { 12. Pengguna mudah mengerti dengan sistem bahasa yang ada } \\
\text { didalam faktur pembelian }\end{array}$ & 0,4 & 3,76 \\
\hline & & f. Training (Pelatihan) & & \\
\hline & & $\begin{array}{l}\text { 13. Ada layanan petunjuk yang disediakan oleh sistem untuk } \\
\text { membantu membantu pengguna baru }\end{array}$ & 0,4 & 3,66 \\
\hline \multirow[t]{3}{*}{3} & \multirow{3}{*}{$\begin{array}{l}\text { Integrity } \\
\text { (Integrtias) } \\
\quad 0,3\end{array}$} & g. Security (Keamanan) & 0,3 & 3,55 \\
\hline & & 14. Hak akses sesuai dengan harapan (ketentuan) & & \\
\hline & & $\begin{array}{l}\text { 15. Aplikasi ini dapat mengontrol akses pengguna dengan } \\
\text { membatasi hak akses }\end{array}$ & 0,4 & 3,68 \\
\hline \multirow[t]{12}{*}{4} & \multirow{12}{*}{ 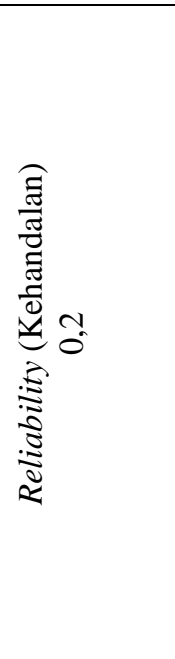 } & h. Accuracy (Akurasi) & & \\
\hline & & $\begin{array}{l}\text { 16. Aplikasi ini mudah dimasukan input yang diperlukan oleh } \\
\text { sistem }\end{array}$ & 0,4 & 3,84 \\
\hline & & 17. Kebutuhan pengguna ditampilkan oleh aplikasi ini dengan tepat & 0,4 & 3,92 \\
\hline & & $\begin{array}{l}\text { 18. Informasi dan data yang disediakan aplikasi ini sesuai dengan } \\
\text { kebutuhan pengguna dan cepat }\end{array}$ & 0,3 & 3,95 \\
\hline & & 19. Informasi sari sistem ini akurat dan bebas kesalahan & 0,4 & 3,84 \\
\hline & & $\begin{array}{l}\text { 20. Pengguna dapat memperoleh informasi yang dibutuhkan dalam } \\
\text { waktu yang tepat }\end{array}$ & 0,4 & 3,95 \\
\hline & & i. Error Tolerancy (Toleransi Kesalahan) & 0,4 & 3,76 \\
\hline & & 21. Akses sistem dibatasi sesuai dengan struktur organisasi yang ada & & \\
\hline & & j. $\quad$ Simplicity (kesederhanaan) & 0,3 & 3,92 \\
\hline & & 22. Pengguna memahami informasi dari sistem dengan mudah & & \\
\hline & & 23. Tampilan menu sangat interaktif & 0,3 & 3,92 \\
\hline & & $\begin{array}{l}\text { 24. Data dan informasi diberikan oleh aplikasi dengan cepat dan } \\
\text { tepat kepada pengguna }\end{array}$ & 0,3 & 3,95 \\
\hline \multirow[t]{3}{*}{5} & \multirow{3}{*}{ 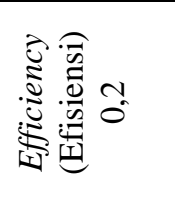 } & k. Execution Efficiency (Kemudahan Eksekusi) & & \\
\hline & & $\begin{array}{l}\text { 25. Menu layanan fungsi dan data yang dibutuhkan sudah sesuai } \\
\text { dengan yang diinginkan }\end{array}$ & 0,3 & 3,95 \\
\hline & & $\begin{array}{l}\text { 26. Fungsi dari isi yang ada di dalam sistem sudah mengakomodasi } \\
\text { penyampaian segala informasi tentang sulaman mayang }\end{array}$ & 0,4 & 4,03 \\
\hline
\end{tabular}


DOI: https://doi.org/10.33330/jurteksi.v6i3.623

Available online at http://jurnal.stmikroyal.ac.id/index.php/jurteksi

\section{Nilai Factor Quality}

Nilai factor quality $(\mathrm{Fa})$ merupakan tahap pencarian nilai masing-masing sub indikator dan indikator, yang nantinya akan menghasilkan suatu nilai dan persentase. Adapun rumus yang digunakan untuk mencari nilai setiap sub indikator yaitu :

$\mathrm{Fa}=\mathrm{w}_{1} \mathrm{c}_{1}+\mathrm{w}_{2} \mathrm{c}_{2}+\mathrm{w}_{3} \mathrm{c}_{3}+\ldots+$ wncn

Dimana :

$\mathrm{Fa}$ : nilai total dari faktor

w:bobot setiap kepentingan

c:nilai dari matrik rata-rata (nilai kriteria)

Perhitungan masing-masing factor quality dilakukan sebagai barikut :

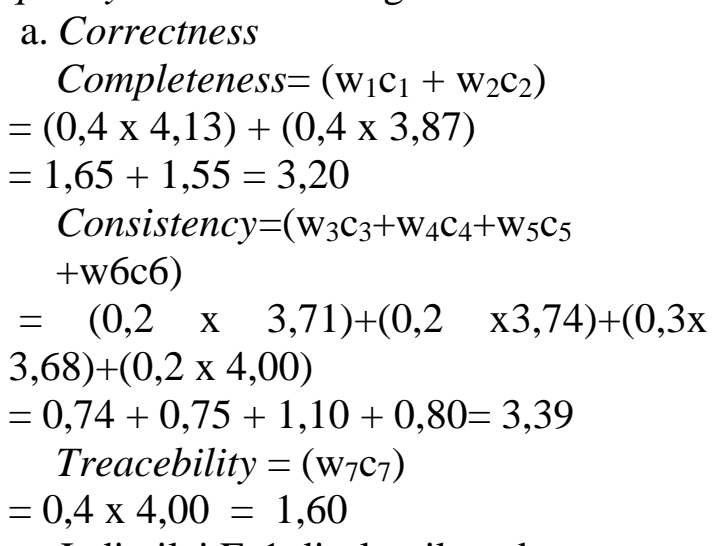

Jadi nilai Fa1 diselesaikan dengan cara berikut:

$F a 1=\frac{\text { Completeness }+ \text { Consistency }+ \text { Tracebility }}{3}$ $=\frac{3,20+3,39+1,60}{3}=2,73$

Berdasarkan kalkulasi diatas maka perlu dihitung nilai Quality factor yang diubah dalah bentuk persentase berupa persamaan:

$$
\begin{aligned}
& \text { Integrity } \\
& \quad \text { Security }=\left(\mathrm{w}_{1} \mathrm{c}_{1}+\mathrm{w}_{2} \mathrm{c}_{2}\right) \\
& =(0,3 \times 3,55)+(0,4 \times 3,68) \\
& =1,07+1,47=2,54
\end{aligned}
$$$$
\text { Persentase }=\frac{\text { Nilai yang didapat }}{\text { Nilai Maksimum }} \times 10
$$$$
=\frac{3,11}{5} \times 100 \%=62 \%
$$

Jadi nilai Fa3 diselesaikan dengan cara berikut:

$$
\begin{aligned}
\text { Fa3 } & =\frac{\text { Security }}{1} \\
& =\frac{2,54}{1}=2,54
\end{aligned}
$$

Dilanjutkan dengan menghitung faktor kualitas dengan persamaan:

Persentase

$$
\begin{aligned}
& =\frac{\text { Nilai yang didapat }}{\text { Nilai Maksimum }} \times 100 \% \\
& =\frac{2,54}{5} \times 100 \%=51 \%
\end{aligned}
$$

Pada faktor kualitas integrity, pengujian juga dilakukan terhadap security (terpenuhinya mekanisme untuk mengontrol dan melindungi program ataupun data terhadap hak akses dari pihak yang tidak berkepentingan). Total aktifitas yang diuji sebanyak 5 fiture. Aplikasi sulaman mayang tersebut telah memenuhi 3 fitur. Hasil pengujian security disajikan dalam tabel 4.

Berdasarkan tabel 4 dinyatakan bahwa security sistem dari aplikasi sulaman mayang memiliki nilai $60 \%$. Dari hasil persentase yang diperoleh dari perhitungan sebelumnya (Perhitungan persentase akses kontrol dan security), dilanjutkan dengan mengubah nilai faktor menggunakan persamaan.

Tabel 4. Hasil Penilaian Kualitas Sistem Informasi Sulaman Mayang

\begin{tabular}{llc}
\hline No & \multicolumn{1}{c}{ Activity } & $\begin{array}{c}\text { Hasil } \\
\text { Pengujian }\end{array}$ \\
\hline 1 & Login & Ada \\
\hline 2 & Session Logout & Ada \\
\hline 3 & Level User & Tidak Ada \\
\hline 4 & Enskripsi & Ada \\
& Password & \\
\hline 5 & Enskripsi Url & Tidak Ada \\
\hline
\end{tabular}


DOI: https://doi.org/10.33330/jurteksi.v6i3.623

Available online at http://jurnal.stmikroyal.ac.id/index.php/jurteksi

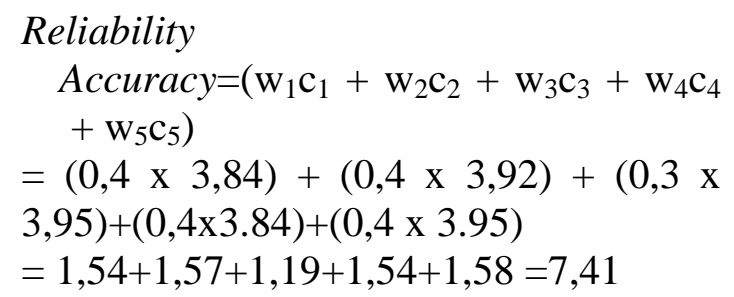

Error Tolerancy $=($ w6c6 $)$

$=(0,4 \times 3,76)$

$=1,50$

Simplicity $=\left(\mathrm{w}_{7} \mathrm{c}_{7}+\mathrm{w}_{8} \mathrm{c}_{8}\right)$

$=(0,3 \times 3,92)+(0,3 \times 3,92)$

$=1,18+1,18=2,35$

Jadi nilai Fa4 diselesaikan dengan cara berikut:

$$
\begin{aligned}
F a 4 & =\frac{\text { Accuracy }+ \text { Error Tolerancy }+ \text { Simplicity }}{3} \\
& =\frac{7,41+1,50+2,35}{3}=3,76
\end{aligned}
$$

Aktivitas berikutnya memperoleh perhitungan faktor kualitas menggunakan persamaan:

$$
\begin{aligned}
\text { Persentase } & =\frac{\text { Nilai yang didapat }}{\text { Nilai Maksimum }} \times 100 \% \\
& =\frac{3,76}{5} \times 100 \%=75 \%
\end{aligned}
$$

\section{e. Efficiency}

Execution Efficiency $=\left(\mathrm{w}_{1} \mathrm{c}_{1}\right)+\left(\mathrm{w}_{2} \mathrm{c}_{2}\right)$

$=(0,3 \times 3,95)+(0,4 \times 4,03)$

$=1,19+1,61=2,80$

Jadi nilai Fa5 diselesaikan dengan cara berikut:

$$
\begin{gathered}
\text { Fa5 }=\frac{\text { Execut ?on Efficiency }}{1} \\
=\frac{2,80}{1}=2,80
\end{gathered}
$$

Kemudian melakukan penentuan faktor kualitas dengan menggunakan persamaan:

Persentase $=\frac{\text { Nilai yang didapat }}{\text { Nilai Maksimum }} \times 100 \%$

$$
=\frac{2,80}{5} \times 100 \%=56 \%
$$

Aspek fungsionality hasil kuisioner yang diperoleh dari 38 responden tersebut dilakukan perhitungan persentase dengan persamaan rumus sebagai berikut

Persentase Fungsionality

$$
=\frac{\text { Nilai yang didapat }}{\text { Nilai Maksimum }} \times 100 \%
$$

Maka, perhitungan persentase fungsionality tersebut seperti ini :

$$
\begin{aligned}
& \sum \\
& =\frac{(0,3 * \mathrm{Fa} 1)+(0,3 * \mathrm{Fa} 2)+(0,3 * \mathrm{Fa} 3)+(0,2 * \mathrm{Fa} 4)+(0,2 * \mathrm{Fa} 5)}{\text { Nilai Maksimum }} \times 100 \% \\
& = \\
& \frac{(0,3 * 2,73)+(0,3 * 3,11)+(0,3 * 2,54)+(0,2 * 3,76)+(0,2 * 2,80)}{5} \times 100 \% \\
& =\frac{0,819+0,933+0,762+0,752+0,56}{5} \times 100 \% \\
& =\frac{3,824}{5} \times 100 \%=76 \%
\end{aligned}
$$

Hasil persentase di atas kemudian dibandingkan dengan skala likert. Pengelompokan tingkat persentase sesuai dengan kategori kelayakan pada tabel 3 . Maka dapat disimpulkan bahwa Aplikasi sulaman mayang secara total berada pada level antar $61 \%-80 \%=76 \%$ dan termasuk dalam kategori BAIK.

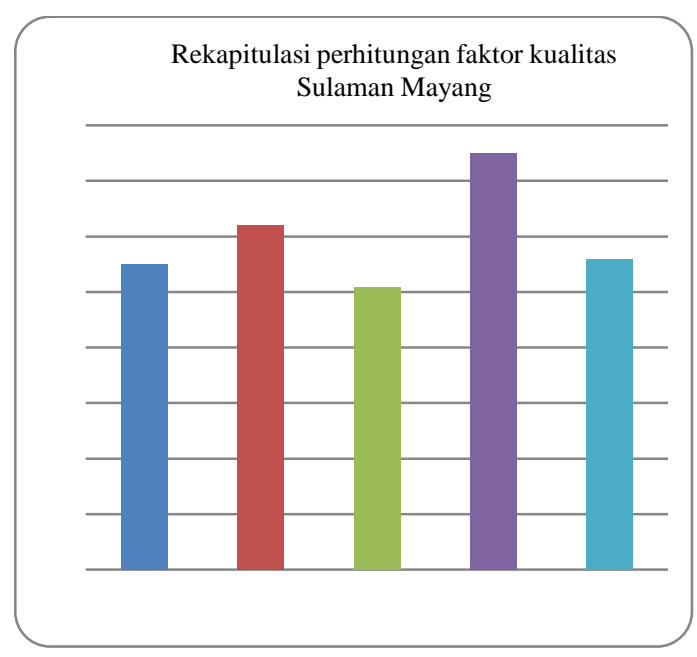

Gambar 5. Perhitungan Faktor Kualitas 
Penilaian terendah berdasarkan grafik tersebut terdapat pada faktor kualitas integrity dengan persentase $51 \%$ (Cukup baik). Hal tersebut berkaitan dengan saran yang diberikan oleh responden terhadap kinerja pengembangan sistem untuk melakukan pengamanan terhadap sistem. Pengamanan sebelumnya dari sistem tersebut hanya mengacu kepada satu aktor/pengguna saja yang berlaku sebagai admin sehingga pemisahan hak akses tidak dilakukan, seharusnya sistem tersebut juga memunculkan level user untuk masing-masing pengguna dan enskripsi password.

Kategori terendah berikutnya adalah correctness dengan nilai 55\% (Cukup baik) dan Effisiensi responden memiliki nilai 56\% (Cukup baik) dikarenakan sistem informasi sulaman mayang belum memenuhi kebutuhan pengguna dalam hal informasi dan pelayanan yang dilakukan dengan cepat. Pelanggan selalu menunggu waktu antrian untuk dilayani pihak usaha/karyawan ketika membutuhkan informasi yang baru mengenai sulaman. Dan dari aspek correctnest menurut responden disebabkan oleh informasi seputar sulaman mayang di Kota Pariaman yang ditampilkan belum lengkap, belum jelas dan pengguna susah untuk mendapatkan informasi mengenai sulaman tersebut. Dan responden meminta untuk bisa mengakses sistem secara langsung melalui smartphone masing-masing.

Berdasarkan hasil analisa dan perhitungan terhadap 5 faktor tersebut penulis dapat menemukan kekurangan dan kelebihan pada sulaman mayang. Berdasarkan kekurangan tersebut penulis memberikan rekomendasi sebagai pandangan untuk pengembangan/ perbaikan sistem di sulaman mayang kota Pariaman seperti pada tabel 6.
Tabel 6 Rekomendasi sistem

\begin{tabular}{clr}
\hline No & \multicolumn{3}{c}{ Rekomendasi } \\
\hline 1 & $\begin{array}{l}\text { Sebaiknya pengelola sulaman } \\
\text { mayang lebih memperhatikan }\end{array}$ \\
& kemudahan penggunaan sistem \\
\hline 2 & Sebaiknya pengelola sulaman \\
& mayang melakukan training \\
& terhadap penggunaan sistem \\
& secara langsung, seperti \\
& memberikan layanan \\
& perubahan pasword pada sistem \\
& dan memberikan tingkatan \\
& penggunaan sistem. \\
\hline 3 & Sebaiknya pada tampilan dan \\
& tata letak informasi serta fitur- \\
& fitur pada sulaman mayang \\
& lebih di perhatikan dan di tata \\
& ulang agar mudah dipahami \\
& oleh pengguna \\
& dibutuhkan. \\
\hline 4 & Seharusnya pengelola sulaman \\
& mayang memberikan sistem \\
& baru berupa website yang bisa \\
& diakses cepat oleh pengguna \\
\hline 5 & Sistem yang baru seharusnya \\
& memberikan layanan diskusi \\
& /chatting mengenai sulaman \\
tersebut.
\end{tabular}

\section{SIMPULAN}

Berdasarkan penelitian yang telah dilakukan, dapat disimpulkan bahwa metode McCall dapat diterapkan dan dijadikan patokan untuk pengujian kualitas sistem informasi sulaman mayang. Metode tersebut memiliki kriteria paling lengkap dan mendalam, ada beberapa aspek yang dikaji dalam metode McCall diantaranya product operation, product revision dan product transition.

Hasil pengujian kualitas sistem informasi pada sulaman mayang di Kota 
DOI: https://doi.org/10.33330/jurteksi.v6i3.623

Available online at http://jurnal.stmikroyal.ac.id/index.php/jurteksi

Pariaman dengan menggunakan metode McCall ini berdasarkan aspek product operation adalah sebagai berikut: nilai untuk faktor kualitas correctness dengan nilai $55 \%$ (cukup baik), usability $62 \%$ (baik), Integrity 51\% (cukup baik), reliability $75 \%$ ( Baik) dan efisiensi $56 \%$ ( Baik). Secara keseluruhan berdasarkan kategori product operation sistem informasi sulaman mayang memiliki kualitas baik dengan nilai $76 \%$.

Pengujian diselesaikan secara keseluruhan dengan harapan peneliti selanjutnya mampu melakukan pengujian terhadap semua kategori pada teori kualitas McCall agar hasil penelitian lebih komprehensif dan semakin membantu pengembangan sistem informasi sulaman mayang.

\section{UCAPAN TERIMAKASIH}

Terima kasih diucapkan kepada Dirjen Perguruan Tinggi dan Yayasan Perguruan Tinggi Komputer Padang dan Universitas Putra Indonesia yang sudah mendanai Penelitian Terapan penulis.

\section{DAFTAR PUSTAKA}

[1] Seruni, D. (2014). Analisis Komparatif Bauran Pemasaran Hasil Indutri Rumah Tangga Keripik Ubi Di Bireuen Dan Saree. Etd Unsyiah.

[2] Subhiyakto, E. R., \& Utomo, D. W. (2016). Strategi, Teknik, Faktor Pendukung Dan Penghambat Pengujian Untuk Pengembang Perangkat Lunak Pemula. In Seminar Nasional Teknologi Informasi Dan Komunikasi (Vol. 2016, Pp. 236-241).
[3] Widodo, W. (2016). Evaluasi Proses Pengembangan Perangkat Lunak Pada Virtual Team Development Menggunakan Cmmi Versi 1.3. Jurnal Informatika, 10(1).

[4] Ritzkal, R., \& Goeritno, A. (2017). Pengukuran Kualitas Perangkat Lunak Sistem E-Learning Menggunakan Metric Function Oriented. Prosiding Snatif, 769776.

[5] Millah, N. (2015). Pengujian Faktor Correctness Dan Usability Sistem Informasi Kepegawaian Uin Sunan Kalijaga Yogyakarta Menggunakan Metode Mccall. Yogyakarta: Skripsi Teknik Informatika, Uin Sunan Kalijaga.

[6] Yurindra, Y. (2019, December). Pembobotan Dan Penilaian Aplikasi Reservasi Hotel Menggunakan Metode Mccall. In Sensitif: Seminar Nasional Sistem Informasi Dan Teknologi Informasi (Pp. 439-450).

[7] Susanti, E. (2017). Penilaian Kualitas Usability E-Learning Menggunakan Metode Mccall. Tekinfo: Jurnal Ilmiah Teknik Industri Dan Informasi, 5(2), 81-93.

[8] Ikhsan, A. N. (2016). Pengujian Perangkat Lunak Berdasarkan Teori Kualitas Mccall Pada Sistem Student Service Center Stmik Amikom Purwokerto (Doctoral Dissertation, Universitas Amikom Purwokerto).

[9] Yurindra, Y. (2019, December). Pembobotan Dan Penilaian Aplikasi Reservasi Hotel Menggunakan Metode Mccall. In Sensitif: Seminar Nasional Sistem Informasi Dan Teknologi Informasi (Pp. 439-450). 
DOI: https://doi.org/10.33330/jurteksi.v6i3.623

Available online at http://jurnal.stmikroyal.ac.id/index.php/jurteksi

[10] Hidayati, A., Oktariza, E., Rosmaningsih, F., \& Lathifah, S. A. (2017). Analisa Kualitas Perangkat Lunak Sistem Informasi Akademik Menggunakan Mccall. Multinetics, 3(1), 48-53.

[11] Tarmudin, M. (2018). Evaluasi Kualitas Pada Sistem Informasi Perpustakaan Kabupaten Indramayu Menggunakan Model Mccall Quality (Doctoral Dissertation, University Of Muhammadiyah Malang).

[12] Hidayat, H. T., \& Husaini, H. (2019, January). Uji Kelayakan Sistem Informasi Akademik Menggunakan Faktor Kualitas Mccall. In Prosiding Seminar Nasional Politeknik Negeri Lhokseumawe (Vol. 2, No. 1). 